\title{
KEMAMPUAN BERPIKIR KREATIF: PROBLEM BASED LEARNING VS DISCOVERY LEARNING
}

\author{
Riskawati $^{1, a}$, Rezkawati Saad $^{2, b}$ \\ ${ }^{1,2}$ Universitas Muhammadiyah Makassar \\ e-mail: ${ }^{a}$ riskawati@unismuh.ac.id, ${ }^{b}$ rezkawatisaad@gmail.com
}

\begin{abstract}
Abstrak
Tujuan utama dalam penelitian ini adalah untuk menganalisis perbedaan keampuan berpikir kreatif peserta didik antara kelas Problem Based Learning dengan kelas discovery learning. Jenis penelitian yang digunakan adalah penelitian True Experiment dengan menggunakan desain Posttest-Only Control Design. Sampel dalam penelitian adalah kelas XI MIPA 3 sebagai kelas eksperimen dan XI MIPA 2 sebagai kelas kontrol. Data penelitian yang diperoleh dianalisis dengan menggunakan analisis deskriptif dan analisis inferensial. Instrumen penelitian yang digunakan adalah tes kemampuan berpikir kreatif dalam bentuk soal essay. Hasil penelitian menunjukkan bahwa kemampuan berpikir kreatif peserta didik kelas XI MIPA 3 yang diajar menggunakan model Problem Based Learning memperoleh skor rata-rata sebesar 56,3. Sedangkan kemampuan berpikir kreatif peserta didik kelas XI MIPA 2 SMA yang diajar menggunakan model discovery learning memperoleh skor rata-rata sebesar 51,7, dan pada analisis inferensial menunjukkan terdapat perbedaan kemampuan berpikir kreatif peserta didik yang diajar menggunakan model Problem Based Learning dan yang diajar dengan menggunakan model discovery learning, akan tetapi perbedaan yang diperoleh tidak signifikan.
\end{abstract}

Kata kunci: Berpikir Kreatif, Discovery Learning, Problem Based Learning

\section{CREATIVE THINKING ABILITY: PROBLEM BASED LEARNING VS DISCOVERY LEARNING}

\begin{abstract}
The main objective of this study is to analyze the differences in students' creative thinking skills between the Problem Based Learning class and the discovery learning class. The type of research used is True Experimental research using Posttest-Only Control Design. The sample in this study was class XI MIPA 3 as the experimental class and XI MIPA 2 as the control class. The research data obtained were analyzed using descriptive analysis and inferential analysis. The research instrument used was a test of creative thinking skills in the form of essay questions. The results showed that the creative thinking skills of students in class XI MIPA 3 who were taught using the Problem Based Learning model obtained an average score of 56.3. While the creative thinking skills of students in class XI MIPA 2 SMA who are taught using the discovery learning model get an average score of 51.7, and the inferential analysis shows that there are differences in the creative thinking abilities of students who are taught using the Problem Based Learning model and those taught by using the discovery learning model, but the differences obtained are not significant.
\end{abstract}

Keywords: Creative Thinking, Problem Based Learning, Discovery Learning

\section{PENDAHULUAN}

Pembelajaran di kelas merupakan sebuah proses dimana peserta didik mengembangkan semua potensi pada dirinya untuk memperoleh pengetahuan-pengetahuan baru, kemampuan baru, serta cara berpikir baru. Cara berpikir tersebut dapat dirangsang melalui pembelajaran yang mengandung kemampuan berpikir tingkat tinggi. Adapun

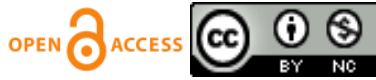


salah satu kemampuan berpikir tingkat tinggi yang dapat digunakan untuk menyelesaikan suatu permasalahan dalam proses pembelajaran adalah kemampuan berpikir kreatif pada peserta didik. Kemampuan berpikir kreatif merupakan suatu komponen yang penting ditumbuhkan pada diri peserta didik. Berpikir kreatif juga penting untuk kesuksesan seseorang, besarnya kreatif masyarakat dalam bangsa tersebut dan penerus bangsa yang sangat menentukan keberadaan bangsa di masa depan adalah peserta didik.

Hasil Observasi yang telah dilakukan di SMA Negeri 11 Bulukumba menunjukkan bahwa rata-rata nilai ujian semester kelas XI MIPA yang berjumlah 86 orang peserta didik masih ada beberapa yang mendapatkan nilai dibawah KBM. Adapun data yang diperoleh pada kelas XI MIPA yakni: (1) kelas XI MIPA 1 yang terdiri dari 28 orang terdapat 25 orang yang tuntas dan 3 tidak tuntas, (2) kelas XI MIPA 2 yang terdiri dari 29 orang terdapat 23 orang yang tuntas dan 6 tidak tuntas, (3) kelas XI MIPA 3 yang terdiri dari 29 orang terdapat 19 orang yang tuntas dan 10 tidak tuntas. Data tersebut menunjukkan bahwa hasil belajar peserta didik kelas XI MIPA SMA Negeri 11 Bulukumba secara keseluruhan sudah lebih dari $50 \%$ peserta didik yang memenuhi KBM. Akan tetapi ada 19 peserta didik yang masih memperoleh nilai di bawah KBM, khususnya kelas XI MIPA 3. Hasil belajar yang tidak maksimal tersebut disebabkan karena kemampuan berpikir kreatif peserta didik dalam proses pembelajaran masih kurang. kemampuan berpikir kreatif mempengaruhi hasil belajar peserta didik yang diperkuat pada pemikiran tingkat tinggi [1].

Ketika berpikir kreatif dapat dikembangkan dengan baik maka berdampak positif pada hasil belajar peserta didik [2] [3]. Hubungan kemampuan berpikir kreatif, motivasi dengan hasil belajar melalui model PBL menunjukkan bahwa terjadi hubungan yang sedang antara kemampuan berpikir kreatif dengan hasil belajar sedangkan arah hubungan positif, karena nilai $r$ positif, berarti semakin tinggi kemampuan berpikir kreatif maka semakin tinggi hasil belajar begitupun sebaliknya [4]. Salah satu faktor mempengaruhi rendahnya kemampuan berpikir kreatif adalah ketika selama proses belajar mengajar berlangsung ternyata peserta didik lebih banyak atau hanya belajar secara verbal saja akan tetapi untuk menerapkan apa yang sudah diajarkan mengalami kesulitan. Faktor tersebutlah yang mengakibatkan peserta didik sulit memahami materi pelajaran fisika sehingga kemampuan berpikir kreatif menjadi rendah.

Dalam proses pembelajaran khususnya dalam pembelajaran fisika berlangsung guru harus mampu memiliki cara pembelajaran yang tepat agar tercapai tujuan pembelajaran yang diinginkan. Salah satunya berkaitan dengan model pembelajaran yang digunakan oleh guru dalam proses pembelajaran. Model pembelajaran Problem Based Learning dan discovery learning merupakan model pembelajaran yang cocok dengan materi fisika, Dalam proses pembelajarannya peserta didik harus ditempatkan pada masalah dan pemecahan masalah yang berkaitan langsung dengan kehidupan nyata sehingga peserta didik mampu memahami materi fisika lebih baik [5][6][7]. Pembelajaran fisika dengan menggunakan Problem Based Learning dapat meningkatkan daya tarik dan minat dalam mempelajari fisika. Model Problem Based Learning merupakan pembelajaran berfokus pada pengalaman pembelajaran yang diatur meliputi penyelidikan dan pemecahan masalah, dalam setiap pembelajaran diberikan masalah harus diselesaikan oleh peserta didik khususnya masalah berkaitan dengan kehidupan sehari-hari [8].

Pengaruh model Problem Based Learning terhadap kemampuan berpikir kreatif peserta didik SMA menunjukkan bahwa penggunaan model Problem Based Learning dalam pembelajaran fisika dapat memberikan ruang kepada peserta didik untuk mengoptimalkan kemampuan berpikir kreatif yang dimiliki peserta didik [9]. Model problem based learning adalah salah satu model pembelajaran yang bisa meningkatkan kemampuan berpikir kreatif peserta didik. Selain itu dari model discovery learning juga dapat membantu peserta didik lebih kreatif dalam berpikir yang berdampak pada prestasi belajar fisika yang meningkat. Hal ini disebabkan karena model discovery learning menyajikan masalah-masalah yang bersifat terbuka sehingga membuat peserta didik lebih aktif berpikir [10][11][12].

Berdasarkan beberapa uraian di atas dapat disimpulkan bahwa model problem based learning dan discovery learning 
merupakan model yang dapat menjadi alternatif dalam proses pembelajaran untuk meningkatkan kemampuan berpikir kreatif peserta didik yang dapat berdampak pada hasil belajar fisika.

\section{METODE}

Jenis penelitian yang digunakan adalah penelitian True Experiment dengan menggunakan desain penelitian Posttest-Only Control Design. Populasi dalam penelitian ini adalah peserta didik kelas XI MIPA SMA Negeri 11 Bulukumba, tahun ajaran 2019/2020 yang terdiri dari 3 kelas, dengan teknik pengambilan sampel dalam penelitian ini menggunakan teknik simple random sampling yaitu dengan cara pengundian, sehingga terpilih kelas XI MIPA 3 sebagai kelas eksperimen dengan jumlah 27 orang dan kelas XI MIPA 2 sebagai kelas kontrol yang berjumlah 31 orang. Teknik pengumpulan data digunakan Instrumen penelitian berupa tes kemampuan berpikir kreatif dalam bentuk essay. Adapun teknik penskoran yaitu sesuai dengan mengikuti rubrik penilaian masingmasing indikator. Dan setelah divalidasi pada populasi yang bukan sampel yaitu kelas XI MIPA 1 terdapat 10 butir soal yang valid. Teknik analisis data kemampuan berpikir kreatif digunakan analisis deskriptif dan analisis inferensial.

\section{HASIL DAN DISKUSI}

Pengambilan sampel diperoleh kelas XI MIPA 3 sebagai kelas eksperimen yang menggunakan model problem based learning dan kelas XI MIPA 2 sebagai kelas kontrol yang menggunakan model discovery learning. berdasarkan analisis deskriptif dan analisis inferensial, maka diperoleh data untuk kedua kelas tersebut.

Analisis Deskriptif Untuk Kelas Eksperimen

Hasil analisis deskriptif skor tes kemampuan berpikir kreatif peserta didik pada kelas kelas eksperimen di SMA Negeri 11 Bulukumba yang diajar menggunakan model problem based learning materi fluida statis dan fluida dinamis, dapat dilihat pada Tabel 1 berikut:
Tabel 1. Statistik Skor Kemampuan Berpikir Kreatif Peserta Didik Kelas Eksperimen

\begin{tabular}{lc}
\hline Statistik & Nilai Statistik \\
\hline Subjek & 27 \\
\hline Skor ideal & 80 \\
\hline Skor tertinggi & 68 \\
\hline Skor terendah & 39 \\
\hline Skor rata-rata & 56,33 \\
\hline Standar deviasi & 8,21 \\
\hline Varians & 67,40 \\
\hline \multicolumn{1}{c}{ Berdasarkan } & Tabel $1, \quad$ diperoleh
\end{tabular}
gambaran bahwa peserta didik yang berada pada kelas eksperimen memiliki jumlah sampel sebanyak 27. Dilihat dari skor tertinggi dari kemampuan berpikir kreatif peserta didik pada kelas eksperimen dicapai skor sebesar 68 dan skor terendah yang dicapai peserta didik sebesar 39 dari skor ideal 80. Adapun skor rata-rata peserta didik sebesar 56,33, standar deviasi sebesar 8,21 dan varians sebesar 67,40.

Distribusi interval skor kemampuan berpikir kreatif peserta didik dikategorisasikan dalam skala lima yaitu sangat rendah, rendah, sedang, tinggi dan sangat tinggi, maka akan diperoleh hasil seperti pada Tabel 2 berikut:

Tabel 2. Distribusi Frekuensi dan Kategorisasi Skor Kemampuan Berpikir Kreatif Kelas Eksperimen

\begin{tabular}{llc}
\hline $\begin{array}{c}\text { Interval } \\
\text { skor }\end{array}$ & Kategori & Frekuensi \\
\hline $63-68$ & Sangat Tinggi & 7 \\
\hline $57-62$ & Tinggi & 6 \\
\hline $51-56$ & Sedang & 7 \\
\hline $45-50$ & Rendah & 5 \\
\hline $39-44$ & Sangat Rendah & 2 \\
\hline Jumlah & & 27 \\
\hline Dari & Tabel 2 di atas dapat diketahui
\end{tabular}
bahwa pada kelas eksperimen pada rentang 6368 terdapat (7) peserta didik yang memperoleh skor kategori sangat tinggi, pada rentang skor 57-62 terdapat (6) peserta didik memperoleh skor kategori tinggi, pada rentang skor 51-56 terdapat (7) peserta didik memperoleh skor kategori sedang, pada rentang skor 45-50 terdapat (5) peserta didik memperoleh skor kategori rendah dan pada rentang skor 39-44 terdapat (2) peserta didik memperoleh skor kategori sangat rendah.

Adapun diagram kategorisasi skor dan frekuensi kemampuan berpikir kreatif peserta didik pada kelas eksperimen dapat dilihat pada Gambar 1: 


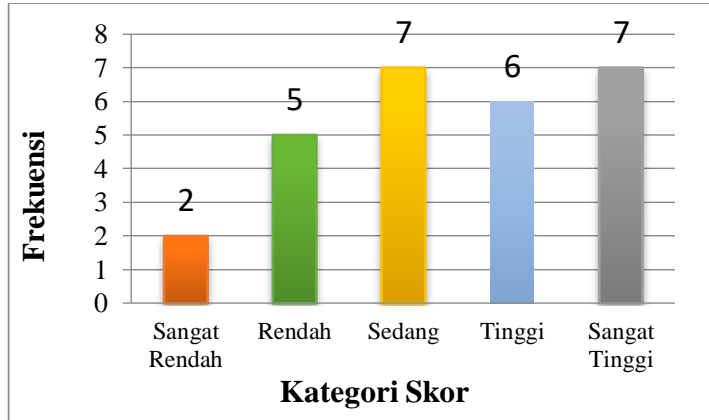

Gambar 1. Diagram Kategorisasi Skor Dan Frekuensi Tes Kemampuan Berpikir Kreatif

Peserta Didik Kelas Eksperimen

Hasil tabulasi persentase skor rata-rata kemampuan berpikir kreatif peserta didik tiaptiap indikator dapat dilihat pada Tabel 3 berikut:

Tabel 3. Persentase Skor Rata-rata Kemampuan Berpikir Kreatif Peserta Didik

Tiap Indikator pada Kelas Eksperimen

\begin{tabular}{lc}
\hline Indikator & Persentase $(\boldsymbol{\%})$ \\
\hline Berpikir Lancar & 71,75 \\
\hline Berpikir Luwes & 51,25 \\
\hline Berpikir Orisinil & 50,92 \\
\hline Berpikir Elaboratif & 89,50 \\
\hline
\end{tabular}

Dari Tabel 3 di atas dapat diketahui bahwa pada indikator berpikir lancar, persentase skor rata-rata peserta didik diperoleh sebesar $71,75 \%$, pada indikator berpikir luwes persentase skor rata-rata peserta didik diperoleh sebesar 51,25\%, pada indikator berpikir orisinil persentase skor rata-rata peserta didik diperoleh sebesar 50,92\%, dan pada indikator berpikir elaboratif persentase skor rata-rata peserta didik diperoleh sebesar $89,50 \%$. Adapun diagram persentase skor ratarata kemampuan berpikir kreatif peserta didik tiap indikator pada kelas eksperimen dapat dilihat pada Gambar 2:

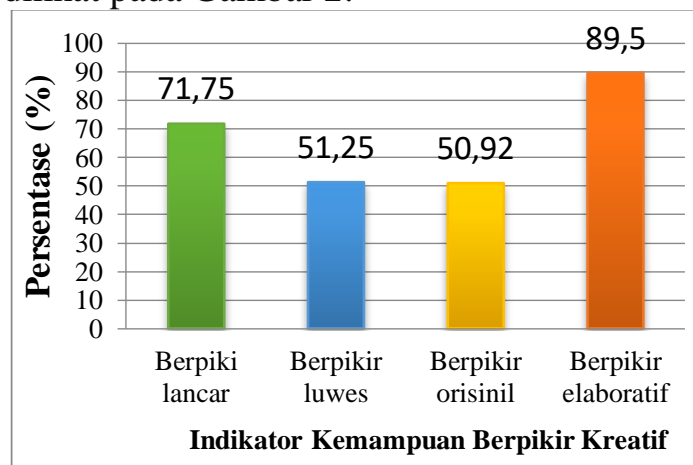

Gambar 2. Diagram Persentase Skor Rata rata Kemampuan Berpikir Kreatif Peserta Didik Tiap Indikator Pada Kelas Eksperimen
Analisis Analisis Deskriptif Untuk Kelas Kontrol

Hasil analisis deskriptif skor tes kemampuan berpikir kreatif peserta didik pada kelas kontrol di SMA Negeri 11 Bulukumba yang diajar menggunakan model Discovery Learning sebagai model konvensional dengan materi fluida statis dan fluida dinamis, dapat dilihat pada Tabel 4 berikut:

Tabel 4. Statistik Skor Kemampuan Berpikir Kreatif Peserta Didik Kelas Kontrol

Statistik Nilai Statistik

\begin{tabular}{|c|c|}
\hline Subjek & 31 \\
\hline Skor ideal & 80 \\
\hline Skor tertinggi & 52 \\
\hline Skor terendah & 11 \\
\hline Skor rata-rata & 51,70 \\
\hline Standar deviasi & 11,07 \\
\hline Varians & 122,54 \\
\hline
\end{tabular}
gambaran bahwa peserta didik yang berada pada kelas kontrol memiliki jumlah sampel sebanyak 31 orang. Dilihat dari skor tertinggi dari kemampuan berpikir kreatif peserta didik pada kelas kelas kontrol sebesar 52, skor terendah sebesar 11, skor ideal sebesar 80, skor rata-rata yang dicapai peserta didik sebesar 51,70, standar deviasi sebesar 11,07 dan varians sebesar 122,54. Jika distribusi interval skor kemampuan berpikir kreatif peserta didik dikategorisasikan dalam skala lima yaitu sangat rendah rendah, sedang, tinggi dan sangat tinggi, maka akan diperoleh hasil seperti pada Tabel 5 berikut:

Tabel 5. Distribusi Frekuensi dan

Kategorisasi Skor Kemampuan Berpikir Kreatif Kelas Kontrol

\begin{tabular}{|c|c|c|}
\hline $\begin{array}{l}\text { Interval } \\
\text { skor }\end{array}$ & Kategori & Frekuensi \\
\hline $43-52$ & Sangat Tinggi & 11 \\
\hline $35-42$ & Tinggi & 9 \\
\hline 27-34 & Sedang & 4 \\
\hline $19-26$ & Rendah & 4 \\
\hline $11-18$ & Sangat Rendah & 3 \\
\hline Jumlah & & 31 \\
\hline
\end{tabular}

Dari Tabel 5 di atas dapat diketahui bahwa pada kelas kontrol, pada rentang 43-52 terdapat 11 peserta didik dengan kategori sangat tinggi, pada rentang skor 35-42 terdapat (9) peserta didik dengan kategori tinggi, pada rentang 27-34 terdapat (4) peserta didik dengan kategori sedang, pada rentang 19-26 
terdapat (4) peserta didik dengan kategori rendah, sedangkan pada rentang skor 11-18 terdapat (3) peserta didik dengan kategorisasi sangat tinggi.

Adapun diagram kategorisasi skor dan frekuensi kemampuan berpikir kreatif peserta didik pada kelas kontrol dapat dilihat pada Gambar 3:

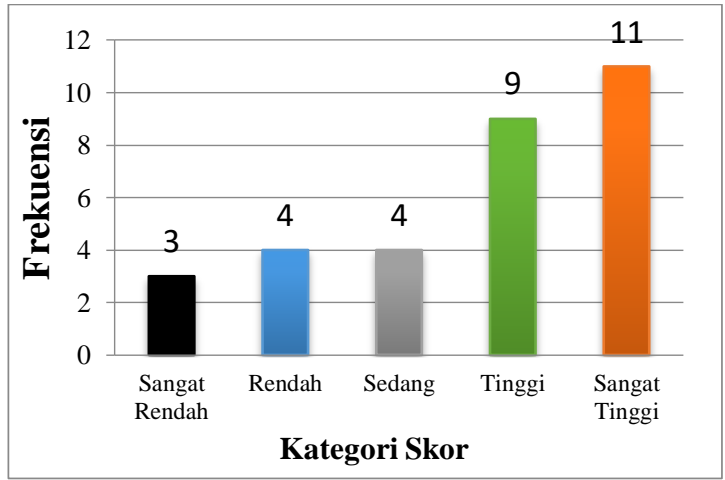

Gambar 3. Diagram Kategorisasi skor dan frekuensi tes kemampuan berpikir kreatif peserta didik kelas kelas kontrol.

Hasil tabulasi persentase skor rata-rata kemampuan berpikir kreatif peserta didik tiaptiap indikator dapat dilihat pada Tabel 6 berikut:

Tabel 6. Persentase Skor Rata-rata

Kemampuan Berpikir Kreatif Peserta Didik

Tiap Indikator pada Kelas Kontrol

\begin{tabular}{ll}
\hline Indikator & Persentase (\%) \\
\hline Berpikir Lancar & 64,70 \\
\hline Berpikir Luwes & 57,67 \\
\hline Berpikir Orisinil & 42,29 \\
\hline Berpikir Elaboratif & 68,69 \\
\hline
\end{tabular}

Dari Gambar 6 di atas dapat diketahui bahwa pada indikator berpikir lancar, persentase skor rata-rata peserta didik diperoleh sebesar $64,70 \%$, pada indikator berpikir luwes persentase skor rata-rata peserta didik diperoleh sebesar $57,67 \%$, pada indikator berpikir orisinil persentase skor rata-rata peserta didik diperoleh sebesar $42,29 \%$, dan pada indikator berpikir elaboratif persentase skor rata-rata peserta didik diperoleh sebesar $58,69 \%$.

Adapun diagram persentase skor ratarata kemampuan berpikir kreatif peserta didik tiap indikator pada kelas eksperimen dapat dilihat pada Gambar 4:

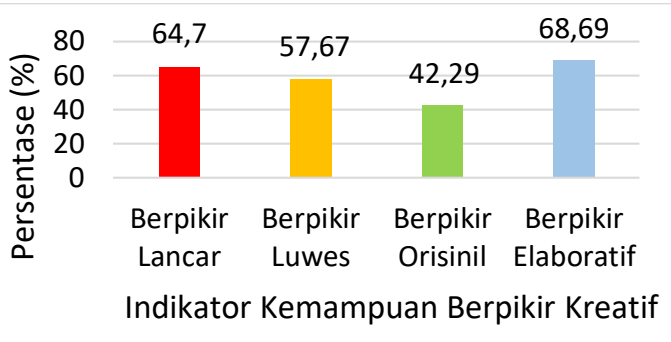

Gambar 4. Diagram persentase skor rata-rata kemampuan berpikir kreatif peserta didik tiap indikator pada kelas kontrol.

\section{Analisis Inferensial}

Setelah hasil pengujian data kedua sampel untuk kelas eksperimen dan kelas kontrol membuktikan bahwa sampel tersebut berdistribusi normal dan mempunyai varian yang homogen, maka selanjutnya data tersebut dapat digunakan untuk pengujian hipotesis. Pengujian hipotesis yang digunakan adalah uji dua pihak dengan kriteria pengujian yaitu Hipotesis nol $\left(\mathrm{H}_{0}\right)$ diterima bilamana $\mathrm{t}_{\text {hit }}<\mathrm{t}(1$ <) (dk) dimana $\mathrm{t}(1-\langle)$ diperoleh dari daftar distribusi $\mathrm{t}$ dengan taraf signifikan $\langle=0,05$. Untuk $\mathrm{H}_{\mathrm{a}}$ diterima bilamana $\mathrm{t}_{\mathrm{hit}}>\mathrm{t}(1-\langle)(\mathrm{dk})$ dengan menentukan $\mathrm{dk}=\mathrm{n}_{1}+\mathrm{n}_{2}-2$, taraf signifikan $\langle=5 \%$ dan peluang $(1-\langle)$.

Berdasarkan hasil pengujian hipotesis penelitian dengan menggunakan uji-t, untuk nilai $t_{\text {hitung }}$ sebesar 3,957 sedangkan $t_{\text {tabel }}$ sebesar 2,003. Hasil yang diperoleh menunjukkan $t_{\text {hitung }}>t_{\text {tabel }}$ yaitu 3,957 > 2,003 yang artinya $\mathrm{H}_{\mathrm{o}}$ ditolak dan $\mathrm{H}_{\mathrm{a}}$ diterima, hal ini menunjukkan berarti terdapat perbedaan kemampuan berpikir kreatif peserta didik kelas yang diajar menggunakan model Problem Based Learning dengan peserta didik kelas yang diajar menggunakan model Discovery Learning sebagai model konvensional.

Penelitian yang berjudul "Penerapan Model Problem Based learning terhadap Kemampuan Berpikir Kreatif Peserta Didik SMA Negeri 11 Bulukumba" memiliki tujuan untuk menganalisis perbedaan kemampuan berpikir kreatif peserta didik antara kelas Problem Based Learning dengan kelas discovery learning. Berdasarkan analisis deskriptif yang telah dilakukan menunjukkan kemampuan berpikir kreatif peserta didik pada kelas eksperimen, terlihat skor rata-rata yang diperoleh peserta didik sebesar 56,33, sedangkan pada kelas kontrol terlihat skor 
rata-rata yang diperoleh peserta didik adalah 51,70. Hal ini menunjukkan bahwa kemampuan berpikir kreatif peserta didik pada kelas eksperimen lebih tinggi dibandingkan dengan kelas kontrol, walaupun perbedaannya sangat kecil. Sedangkan untuk persentase skor tiap-tiap indikator kemampuan berpikir kreatif terdapat tiga indikator yang lebih tinggi di kelas eksperimen dibandingkan dengan kelas kontrol yaitu indikator berpikir lancar, orisinil, dan elaborative. Sedangkan untuk indikator berpikir luwes, kelas kontrol lebih tinggi daripada kelas eksperimen.

Hasil analisis tersebut menunjukkan bahwa kelas eksperimen dominan memiliki nilai lebih tinggi dibandingkan dengan kelas kontrol. Selain itu dapat dilihat dari kedua kelas tersebut indikator elaboratif yang memiliki skor tertinggi, hal ini disebabkan karena peserta didik di SMA Negeri 11 Bulukumba khususnya di kelas XI memiliki tingkat pemikiran yang sangat terperinci dan sistematis terhadap suatu materi. Selain itu indikator elaboratif berkaitan langsung dengan sistem penyusunan model problem based learning, dimana yang perlu diperhatikan dalam merancang masalah adalah sistematis dan sesuai dengan kehidupan nyata [13]. Hal ini sesuai dengan Trianto yang mengemukakan bahwa model pembelajaran yang berbasis masalah memiliki kelebihan membangun kerja sama antar peserta didik dalam menyelesaikan tugas, meningkatkan pengamatan peserta didik dalam proses pembelajaran, melibatkan peserta didik dalam penyelidikan sendiri sehingga peserta didik lebih mandiri dalam berpikir mengenai fenomena berdasarkan fakta serta membangun pemahaman secara terperinci tentang fenomena tersebut [14]. Model problem based learning mampu meningkatkan kreativitas berpikir peserta didik secara signifikan, karena dalam proses pembelajaran $\mathrm{PBL}$ memberikan kesempatan belajar yang berarti pada peserta didik, mengkonstruksi pemahaman melalui pengalaman, berpartisipasi dalam penentuan arah instruksi, sehingga mampu mengembangkan sistem berpikir kreatif peserta didik [15].

Hal tersebut diperkuat oleh Septian yang mengemukakan dalam hasil penelitiannya bahwa kemampuan berpikir kreatif peserta didik dapat meningkat lebih baik dengan model Problem Based Learning dibandingkan dengan model belajar konvensional [16]. Serta sejalan dengan tujuan model Problem Based Learning yang diutaran oleh Bilgin dalam hasil penelitiannya bahwa problem based learning bertujuan untuk membantu peserta didik berpikir, memecahkan masalah, dan meningkatkan keterampilan berpikir mereka dengan membangun situasi nyata atau yang berkaitan dengan konsep yang dipelajari [17], [18]. Oleh karena itu perlu penggunaan model problem based learning pada peserta didik dalam dunia sains khususnya fisika dalam upaya peningkatan kemampuan mereka dalam menghadapi kasus-kasus fisika.

\section{SIMPULAN DAN SARAN}

Berdasarkan hasil analisis data yang diperoleh bahwa kemampuan berpikir kreatif peserta didik kelas eksperimen memperoleh skor rata-rata sebesar 56,33, sedangkan pada kelas kontrol memperoleh skor rata-rata sebesar 51,70. Dan pada uji t diperoleh $t_{\text {hitung }}$ sebesar 3,957 sedangkan $t_{\text {tabel }}$ sebesar 2,003. Hasil yang diperoleh menunjukkan $t_{\text {hitung }}>t_{\text {tabel }}$ yaitu $3,957>2,003$ yang artinya $\mathrm{H}_{\mathrm{o}}$ ditolak dan $\mathrm{H}_{\mathrm{a}}$ diterima, hal ini menunjukkan berarti terdapat perbedaan kemampuan berpikir kreatif peserta didik kelas yang diajar menggunakan model Problem Based Learning dengan peserta didik kelas yang diajar menggunakan model Discovery Learning. Sehingga dapat disimpulkan bahwa model Problem Based Learning memiliki pengaruh dalam meningkatkan kemampuan berpikir kreatif peserta didik.

Sebaiknya untuk menunjang keefektifan pembelajaran berbasis Problem Based Learning dan discovery learning, sebaiknya dibuat suatu buku ajar yang didalamnya mengangkat masalah-masalah nyata yang didasarkan pada kedua model tersebut.

\section{DAFTAR PUSTAKA}

[1] Wahyuni and P. Kurniawan, "Hubungan Kemampuan Berpikir Kreatif Terhadap Hasil Belajar Mahasiswa," Matematika, vol. 17, no. 2, pp. 1-8, 2018, doi: $10.29313 / \mathrm{jmtm} . v 17 \mathrm{i} 2.4114$

[2] W. Agustina and F. Noor, "Hubungan Hasil Belajar Dan Tingkat Berpikir Kreatif Siswa Dalam Pembelajaran Matematika," Math Didact., vol. 2, no. 
3, pp. 191-200, 2016, doi: 10.33654/math.v2i3.49.

[3] A. Bin Jamaluddin, S. Zubaidah, S. Mahanal, and A. Gofur, "Character, creative thinking and learning achievement in higher education: How they are correlated," AIP Conf. Proc., vol. 2330, no. March, 2021, doi: $10.1063 / 5.0043184$.

[4] C. E. Lisa Ariesti Safitri, Undang Rosidin, "Hubungan Kemampuan Berpikir Kreatif Dan Motivasi Dengan Hasil Belajar Melalui Model PBL," J. Relig. Stud., vol. 72, no. 1, pp. 189-193, 1998.

[5] F. Ayu and A. Fauzi, "Practicality Development Of Edmodo-Assisted Physics E-Book Based On Discovery Learning In The Physics Learning Process," J. Inov. Pendidik. dan Sains, vol. 1, no. 3, pp. 66-71, 2020, [Online]. Available:

http://ejournal.unwmataram.ac.id/JIPS/a rticle/view/442/228.

[6] R. Hidayat, L. Hakim, and L. Lia, "Pengaruh Model Guided Discovery Learning Berbantuan Media Simulasi PhET Terhadap Pemahaman Konsep Fisika Siswa," Berk. Ilm. Pendidik. Fis., vol. 7, no. 2, pp. 97-104, 2019, doi: 10.20527/bipf.v7i2.5900.

[7] N. Sudiarti, "Penerapan Model Pembelajaran Problem Based Learning untuk Meningkatkan Hasil Belajar Fisika Materi Suhu dan Kalor," J. Educ. Action Res., vol. 3, no. 4, pp. 440-447, 2019, doi: 10.23887/jear.v3i4.22664.

[8] G. S. Selçuk, "The effects of problembased learning on pre-service teachers' achievement, approaches and attitudes towards learning physics," Int. J. Phys. Sci., vol. 5, no. 6, pp. 711-723, 2010.

[9] A. Elizabeth and M. M. Sigahitong, "Pengaruh Model Problem Based Learning Terhadap Kemampuan Berpikir Kreatif Peserta Didik SMA," Prism. Sains J. Pengkaj. Ilmu dan Pembelajaran Mat. dan IPA IKIP Mataram, vol. 6, no. 2, p. 66, 2018, doi: 10.33394/j-ps.v6i2.1044.

[10] T. Juniarso, "Model Discovery Learning Terhadap Kemampuan Berpikir Kreatif Mahasiswa," ELSE (Elementary Sch.
Educ. Journal), vol. 4, no. 1, pp. 36-43, 2020, doi: 10.30651/else.v4i1.4197.

[11] K. N. Fatmasari, Kamaluddin, and M. Ali, "The Effect of the DiscoveryInquiry Learning Model on Improving the Senior High School Students' Creative Thinking Skills in Material of Physics," J. Kreat. Online, vol. 9, no. 4, pp. 77-85, 2021, [Online]. Available: http://jurnal.fkip.untad.ac.id/index.php/j ko.

[12] E. Andriyani, Muhaimin, and Syaiful, "The Effect Of Self Regulated Learning Model And Discovery Learning Model On Thinking Ability Creative Mathematics," Edumatica J. Pendidik. Mat., vol. 11, no. 3, pp. 54-64, 2021, [Online]. Available: https://onlinejournal.unja.ac.id/edumatica/issue/view/ 1197.

[13] W. Hung, "The Interdisciplinary Journal of Problem-based Learning 10 th Anniversary Section: Past And Future All PBL Starts Here: The Problem," Interdiscip. J. Probl. Learn. Vol., vol. 10, no. 2, 2016.

[14] Trianto Ibnu Badar, Mendesain Model Pembelajaran Inovatif, Progresif, Dan Kontekstual. 2017.

[15] M. Nuswowati and M. Taufiq, "Developing creative thinking skills and creative attitude through problem based green vision chemistry environment learning," J. Pendidik. IPA Indones., vol. 4, no. 2, pp. 170-176, 2015, doi: 10.15294/jpii.v4i2.4187.

[16] R. R. Ari Septian, "Penerapan Model Problem Based Learning (Pbl) Terhadap Peningkatan Kemampuan Berpikir Kreatif Matematis Siswa," Prisma, vol. 6, no. 1, pp. 1-8, 2017, doi: 10.35194/jp.v6i1.22.

[17] I. Bilgin, E. Şenocak, and M. Sözbilir, "The effects of problem-based learning instruction on university students' performance of conceptual and quantitative problems in gas concepts," Eurasia J. Math. Sci. Technol. Educ., vol. 5, no. 2, pp. 153-164, 2009, doi: 10.12973/ejmste/75267.

[18] M. P. Simanjuntak, J. Hutahaean, N. Marpaung, and D. Ramadhani, "Effectiveness of problem-based learning combined with computer 
simulation on students' problem-solving and creative thinking skills," Int. J. Instr., vol. 14, no. 3, pp. 519-534, 2021, doi: 10.29333/iji.2021.14330a. 